\title{
Who Are the Consumers? - The Need for a Sustainability-Integrated Consumer Research Agenda
}

\author{
Prof. Dr. Christa Liedtke \\ Research Group 4: Sustainable Production and Consumption \\ Wuppertal Institute for Climate, Environment and Energy \\ Döppersberg 19, 42103 Wuppertal, Germany
}

Tel.: 49-202-249-2130Ｅ-mail: christa.liedtke@wupperinst.org

Johannes Buhl

Research Group 4: Sustainable Production and Consumption

Wuppertal Institute for Climate, Environment and Energy

Döppersberg 19, 42103 Wuppertal, Germany

Tel.: 49-202-249-2156_E-mail: johannes.buhl@wupperinst.org

\begin{abstract}
Melanie Speck (Corresponding author)
Research Group 4: Sustainable Production and Consumption

Wuppertal Institute for Climate, Environment and Energy

Döppersberg 19, 42103 Wuppertal, Germany
\end{abstract}

Tel.: 49-202-249-2302Ｅ-mail: melanie.lukas@wupperinst.org

Lisa Marie Borrelli

Research Assistant and PhD Candidate

University of Bern, Institute of Sociology, Fabrikstraße 8, 3012 Bern-CH

Tel.: 41-316-314-829Ｅ-mail: lisa.borrelli@ soz.unibe.ch 


\title{
Silvia Monetti
}

University of Freiburg im Breisgau, Faculty of Environment and Natural Resources

Tennenbacher Str. 4, 79106 Freiburg im Breisgau, Germany

E-mail: silviamonetti@hotmail.it

\author{
Received: January 16, 2016 Accepted: February 4, 2016 \\ doi:10.5296/emsd.v5i2.9918ＵRL: http://dx.doi.org/10.5296/emsd.v5i2.9918
}

\begin{abstract}
In order to make our lifestyles sustainable, changing our consumption patterns is fundamental. Hence, we need to better understand who the "consumers" are and to consider them as an active actor to directly engage for ensuring effective policies. In order to support a resource-light society, production and consumption need to be considered through an integrated system view; within this, consumers play an important role as co-acting subjects. Almost every activity in private life involves a form of consumption aimed at satisfying the subject's needs and often regarded through an economic lens. Sustainable development is not about abolishing private consumption, but rather about making it environmentally, socially and individually sustainable in its design, organization and realization, also involving ideas of simplicity or renunciation. In this paper, we will assess the status quo of the German and European debates on Consumer Research Policies and discuss the idea to link sustainability research and consumer research - where a strategic relation is currently missing. Within that discussion, an evidence-based and obligatory consumer research strategy in Germany and Europe would represent a significant improvement. A system view perspective is necessary to take into consideration the impressive amount of diversity, and to elaborate realistic economic and consumer policies. Therefore, we propose nine steps for understanding the role of the consumer in implementing sustainable development from a scientific and political perspective. The limitations of this paper are thus a result of the very diverse and often unclear policies and agendas produced by governments. The implementation of the proposed innovative research agenda for a future-orientated and sustainability-based consumer research is not free from challenges. Still, the paper suggests the first steps towards this direction. After a critical discussion of the current EU and German consumer and sustainability policies, nine differentiated and substantial ways to integrate and ameliorate them are proposed.
\end{abstract}

Keywords: Consumer policy, Consumer research, Sustainability science, Germany, European Union, Research agenda

\section{Introduction}

Creating increasingly innovative technologies to face the challenge of sustainability transitions is not going to have a major impact, as we can learn from the present status of 
sustainable development. According to current research, to achieve this goal we need to modify our consumption patterns and lifestyles. A deeper understanding of the "consumers" and a comprehensive consumer research strategy are therefore needed. From this, our main research questions arise: (i) how a theoretical understanding of the "consumer" and related research has developed within Germany and Europe over the last years, and (ii) how these intertwined arenas can be related to scientific perspectives, to deduce general guiding principles and models for an applied sustainability research. In this regard, policy concepts need to include the consumer as an actor to engage directly. We argue that only a science-based consumer policy, involving actors at all levels, can bring a real transformation. Thus, we will critically reflect on the gaps in the German and European consumer policy and suggest possible steps for improving them.

The framework in which consumers take their decisions is formed not only by economic elements, but also by socio-psychological factors (e.g. limited knowledge and cognitive capacity, rational and utility maximising behaviours, socio-cultural environment) as well as by technological and institutional conditions (e.g. goods supply and policy measures) (Kletzan et al. 2002). Overall, consumers' actions are constrained by a large number of external conditions; therefore, the perspective on sustainable consumption should be broadened to include also elements such as public policies, education, information, and a variety of relevant actors (Schrader \& Thøgersen 2011). Actually, according to some positions, one of the major deficiencies of current sustainability strategies is the lacking of a holistic approach (Sheth et al. 2011). This is important also in the light of the central cultural functions that consumption has increasingly taken up in our society - functions often underestimated by more materialistic approaches (Leismann 2012, 2013).

Accordingly, this paper will assess the status quo of the German and European debate about consumer research (chapter 2). Against this background, the authors will link sustainability and consumer research (chapter 3) and argue for and enlighten a sustainability-related consumer research agenda (chapter 4). Finally, nine steps for understanding the role of the consumer in realizing sustainable development from the perspective of science and politics will be pointed out (chapter 5).

\section{Background: Consumer Research Policies}

In Germany and in the EU, the discourse on the development of a general consumer policy can already count on a decades-long history. In addition, the increasing attention that consumer research and its related disciplines have started to receive in the last years forms the basis for science-based consumer policy decisions. This development was made possible, and still goes on, thanks to various networks for consumer research at different political levels, initiatives, projects, and the public funding of social-ecological research. However, consumer research does not automatically involve a sustainability perspective - which is rather put forward within this article, as the urgency of its inclusion becomes clear when analysing deficiencies of current policies. In order to understand the complex interactions and the development of research strategies and policies, we will especially consider the German and the European perspectives on consumer research. 


\subsection{German Perspective on Consumer Research}

In Germany, two Secretaries of State are currently responsible for the consumer protection in the Federal Ministry of Justice and Consumer Protection (BMJV). Moreover, the Coalition Agreement established in 2013 an independent Advisory Council on Consumer Affairs which had already been called for by parties as well as by scientific and consumer organisations (Oehler \& Kenning 2013: 8) ${ }^{1}$. For several years, the Council repeatedly discussed the principles of a consumer policy and the role of consumers in it. Its insights have been published as statements or discussion papers (Liedtke \& Buhl 2015):

- 2003 strategy called: Principles and models of a new consumer policy

- 2004 strategy called: Consumer policy research

- 2008 strategy/understanding called: Consumer's role for a personally successful and socially responsible consumption

- 2010 strategy/understanding called: The trusting, the vulnerable or the responsible consumer? Pleas for a differentiated strategy in consumer policy

- 2010 strategy/understanding called: Do all really want the "empowered consumer"? How groups of interest instrumentalise guiding principles

- 2012 strategy/understanding called: Is the "empowered consumer" a myth? Towards a realistic consumer policy

- 2013 strategy/understanding called: Make evidence-base possible! Towards a realistic and empirically-based consumer policy

- 2014 strategy/understanding called: Consumer policy for sustainable consumption Consumer policy perspectives for a sustainable transformation of economy and society

(BMELV 2003, 2013)

These titles and the related concepts clearly show the changes in the understanding of consumer policy and research, as well as its emerging in the debate between different and long-standing political, economic, scientific and social actors (Buhl \& Liedtke 2015). Overall, a measurable transition and transformation in our society appears (BMJV 2014a,b,c). To note are also the consistency in the common interpretation of consumer policy and research, and their growing importance. They were made possible by the permanence of long-term networking, ministerial anchoring and personal commitment of political and scientific actors related to consumer policy (Liedtke \& Buhl 2015, Lukas et al. 2014, Stengel 2011).

Significant steps towards more sustainable economies and lifestyles were done and are being

\footnotetext{
1 An overview of activities about consumer research is provided e.g. by the 'Centre of Excellence for Consumer Research NRW, see: (http://www.vz-nrw.de/kvf-links), by the 'consumer portal BaWü', see: (http://www.verbraucherportal-bw.de), and the Bavarian State Ministry of Justice, see: (http://www.bmel.de/DE/Ministerium/Organisation/Beiraete/ Texte/VerbrVeroeffentlichungen.html;jsessionid= 243FCD664AA0C01B10A8D868861561E8.2_cid365
} 


\section{Ml Macrothink}

done (KRU 2014, Dreuw \& Rohn 2013). With regard to the production and consumption systems, this involves an integrated system-view of production and consumption on an equal footing - without which sustainable development could optimize only subsystems, but not make use of the wider sustainability potential (Liedtke et al. 2015a, Baedecker et al. 2014). The last statements of the Council on Consumer Affairs clearly show the struggle for a "realistic" and "empirically-based" consumer policy linked to a "consumer policy perspective for a sustainable transformation of economy and society" (borrowed from titles above) (Oehler \& Reisch 2008). However, a realistic and real-world oriented explanation of the "consumer" is not easy to assess, due to the huge amount of factors and implications affecting consumers' behaviour (Fig. 1):

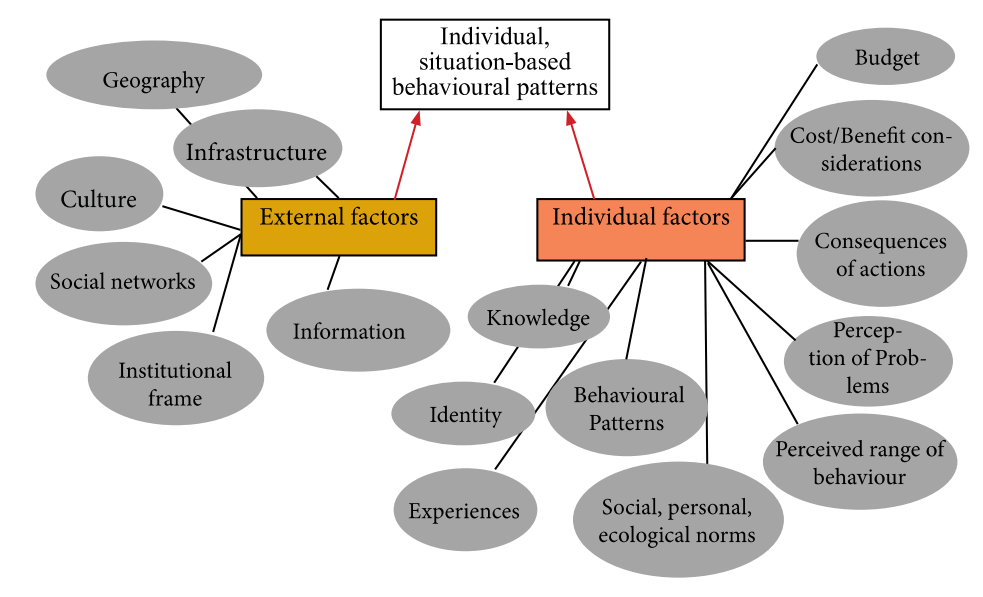

Figure 1: Influential factors of consumers' behaviour (own despiction, based on: Liedtke et al. 2015; Backhaus et al., 2013: 23)

As previously mentioned, consumers' choices are directly or indirectly influenced by several individual and external factors such as budget, culture, infrastructure or knowledge.

From a scientific perspective, different explanatory models with different abstraction levels have been developed: from autonomously acting individuals through systematic information asymmetries (information model) and behavioural pattern mixes (in a person or typologies of social groups), up to responsible consumption, which addresses sustainability; but also individual differentiation over milieu-, setting-, and routine-related behaviours, up to legitimacy of collective interests (Fellner, 2014).

The challenge and the aim is then not to address THE consumer, but rather (i) to support the differentiation and creative variety in finding solutions to manage life(styles), and (ii) to recognize roles and responsibilities also on the side of companies, NGOs and politics (cf. Strünck et al. 2012 p. 12, 2010 and Weisser 1978). Strünck et al. (2012) plead for an in-depth analysis of the consumption patterns and of everyday decisions, as well as for testing interactions and networks between producers, consumers and consumer policy measures.

It should also be noted that, in a realistic picture of consumers' behaviour, they should be involved not only as observed objects, but rather as co-acting subjects. Liedtke \& Buhl (2015) consider the statement about evidence-based consumer research developed by Oehler \& 
Kenning in 2013 (Oehler \& Kenning, 2013) as an important assertion towards a future-orientated research. Oehler \& Kenning (2013) problematize, on the one hand, the function of domestic demand, as named by various interest groups, and its importance for the economy; on the other hand, the strongly differentiated situation of the necessary supply- and demand-side data. They impressively show the intensity of the political and scientific discussion and conclude that "in Germany, a systematic, evidence-based consumer policy is obviously not possible ... This very empirical information would be an important prerequisite for an effective and efficient consumer policy" (Oehler \& Kenning, 2013: 3-4). In order to understand real behaviour and decision-making, data should take into account dynamic changes e.g. in finance, nutrition, health and social security. "In the long run, a database is desirable in order to combine, e.g. in the sustainability field, consistently physical features with social features also in longitudinal sections (panel). In this way, goods consumption, environmental damage and lifestyle differentiation may be considered in an integrated way" (Oehler \& Kenning, 2013: 11).

In conclusion, the absence of a comprehensive and obligatory definition of consumer research in Germany becomes clear. It is all about the development of a first uniform picture that, ideally, would be integrated within a broader, European system. Discussing the current development in Consumer Policy at this level is necessary also for the international cooperation in the European Union.

\subsection{European Perspective}

The "autonomous consumer" is not only proclaimed and discussed on the German policy level, but also plays a key role within the European discussion.

Indeed, in 2012 the European Consumer Agenda was adopted, replacing the Consumer Policy Strategy originally put into place for the period 2007-2013. Strategic goals include the maximisation of consumers' participation and trust in the market, while opening cooperation between international actors. According to the document, 52 out of the 62 measures planned for European consumers have been completed so far, while the remaining 10 are underway.

The Report on Consumer Policy produced by the European Commission, based on information collected during January 2012 and December 2013, was presented as a means of information for other European institutions and to underline the Commission's achievements and initiatives.

Its four major pillars are: safety, knowledge of consumer rights, strengthening of the enforcement of consumer rules, and integrating consumer interests into key sectorial policies.

"Safety" includes improved product traceability throughout the entire supply chain, together with the creation of a more cooperative system of market surveillance across the EU and internationally (see $3^{\text {rd }}$ International Product Safety Week, Commission 2012; RAPEX-China system = information exchange system between EU and China, handling export stops against dangerous products, etc. 1,379 cases between 2006 and mid-2013). In June 2012, the Product Safety Summit (EU, China, US) discussed issues and further steps to improve safety 
surveillance $^{2}$. Another concrete measure for enforcing the Agri-Food Chain Rules is to increase transparency through published information and "rating schemes" for consultation on retailers, restaurants and businesses - connected to the maintenance of a high level of human, animal and plant health protection and animal welfare throughout the chain.

Another key word is "economic growth", the third pillar, which seems to play a major role at the European level (Schrader et al. 2013). Data gathering through, for example, consumer scoreboards to monitor how a Single Market functions for EU consumers, can enlighten current developments. For instance, the Consumer Conditions Scoreboard identifies the persistence of unfair commercial practices and low knowledge of consumer rights among consumers and businesses; the Consumer Markets Scoreboard detects performances related to consumers' conditions (offer comparability, trust in retailers, etc.) on over 50 markets. Results show, among others, that trust in labels is rather limited but consumers are willing to pay more if food labels represent certifications schemes.

The last pillar, "enhancing knowledge and providing information", discusses consumers' decision-making. One achievement and constant aim is to strengthen the European Consumer Centres network (ECC), in order to keep information updated and websites interesting (redesign of Europa Dairy, 2012, updated 2013).

In the next paragraphs, these continuous developments on the European level will be shortly compared with the German Consumer Policy and then critically reflected upon.

\subsection{Comparison Of Consumer Policy Levels}

To propose an enhanced and comprehensive view of consumer research policies, Table 1 presents a short overview of current developments around Consumer Policy on European and German level.

The German case describes more defined tendencies towards a transition of society and evidence-based research, while on the EU level the framework is much broader in variety. Both are not primarily focussed on sustainability - as would rather be necessary to achieve the goal of a resource-light society. Instead, implementing practices for consumer safety around, say, gambling or the individual's right to a bank account, are discussed at the same level of food security and consumer safety regarding production. This is an obvious result of the fairly broad spectrum the European Commission has to work on.

With regard to economic transformations, both sides argue for more transparent information about SME and their sustainable behaviour, in order to ensure consumer's safety. However, even though transparency is considered important, approaches on the European level are mainly based on discussion papers and agendas, which do not consider the implementation of the displayed ideas into detail.

Table 1. European and German Consume Policy - A Comparison (example)

\footnotetext{
2 See Plan for Long Term Cooperation in Safety Surveillance China, EU starting in 2014, and EU regulation 1223/2009 strengthening safety of (cosmetic) products; internationally recognised regime; „It also contributes to better information about the content of cosmetics. The previous ban and the strict regime aiming at phasing out animal testing were not modified“" (European Commission 2014: 16)
} 


\begin{tabular}{|c|c|}
\hline EU Consumer Policy & German Consumer Policy \\
\hline \multicolumn{2}{|l|}{ The "autonomous" consumer and safety } \\
\hline $\begin{array}{l}\text { Mentioned issues: } \\
\text { - } \\
\text { making of thumb" as suboptimal decision } \\
\text { - Low recognition and knowledge of } \\
\text { common pubic logos (e.g. that of paper } \\
\text { recycling) } \\
\text { - Consumer engagement: time plays a } \\
\text { crucial role - little time for important } \\
\text { decisions } \\
\text { - Strong variation within EU concerning } \\
\text { consumer empowerment }\end{array}$ & $\begin{array}{l}\text { Mentioned issues: } \\
\text { - Uninformed decision-making due to } \\
\text { time-constraints } \\
\text { Time as crucial key factor to inhibit rebound } \\
\text { effects } \\
\text { - Education on all actor-levels is not sufficient } \\
\text { Capacities of consumers are wrongly analysed, } \\
\text { interpreted and used }\end{array}$ \\
\hline $\begin{array}{l}\text { Solutions: } \\
\text { - Clear, simple and transparent information; } \\
\text { safety and simplicity of information as key } \\
\text { role and wish of the consumer (binding } \\
\text { since 2014) } \\
\text { Importance of good design for information } \\
\text { disclosure; more advanced testing, } \\
\text { awareness-raising, better comparison tools } \\
\text { needed } \\
\text { - Behavioural analysis of consumers }\end{array}$ & $\begin{array}{l}\text { Solutions: } \\
\text { - Educational programmes need to be established } \\
\text { across all actor-levels } \\
\text { Transparent information on products, businesses } \\
\text { and ingredients } \\
\text { - Consumers need to be analysed: time capacity } \\
\text { (monitor time management and the actively done } \\
\text { choices, monitor routines and ability to change, } \\
\text { find regimes which can trigger change) }\end{array}$ \\
\hline \multicolumn{2}{|l|}{ Value and Food Chains } \\
\hline $\begin{array}{l}\text { - Transparency of value chains throughout } \\
\text { the whole production chain (nowadays } \\
\text { mostly international products, therefore } \\
\text { clear-cut framework necessary) } \\
\text { - } \begin{array}{l}\text { Proposal of e.g. "from farm-to-fork policy } \\
\text { (2013) } \\
\text { Strong policies about food and animal } \\
\text { safety }\end{array}\end{array}$ & $\begin{array}{l}\text { - Government programme (rural development) for } \\
\text { new technologies and strategies enhancing rural } \\
\text { capacities } \\
\text { Modell: "Rural Revival" for innovative ideas } \\
\text { based on people living in rural areas } \\
\text { - Strong policies about food and animal safety }\end{array}$ \\
\hline \multicolumn{2}{|l|}{ The Market and Economy } \\
\hline $\begin{array}{l}\text { - Market growth and compatibility with } \\
\text { - } \quad \text { Martainable and safe products } \\
\text { traceability (e.g. "Product Safety and } \\
\text { Market Surveillance Package" 2013; EU } \\
\text { Cosmetic Products Notification Portal) } \\
\text { - Consumer Conditions and Markets } \\
\text { Scoreboards }\end{array}$ & $\begin{array}{l}\text { Innovation friendly frame for business and SME } \\
\text { development (see digital agenda) and } \\
\text { transparency regulations } \\
\text { Standards of products need to be kept high, e.g. } \\
\text { through assessments (Stiftung Warentest as a } \\
\text { leading German consumer safety group) }\end{array}$ \\
\hline \multicolumn{2}{|l|}{ Research and Institutions } \\
\hline $\begin{array}{l}\text { - Consumer Protection Cooperation (CPC) } \\
\text { to connect national consumer authorities } \\
\text { - } \quad \text { Improve education materials } \\
\text { - Consumer Scoreboards as tool to monitor } \\
\text { how the single market is functioning } \\
\text { - Project 'Role of health related claims and } \\
\text { symbols in consumer behaviour } \\
\text { (CYMBOL)' 2012-2016 }\end{array}$ & $\begin{array}{l}\text { - Council on Consumer Affairs established in } \\
2014 \text { (assist Federal Government, take into } \\
\text { account consumer interests, expert opinion and } \\
\text { recommendations) } \\
\text { - Takes over task of former Scientific Committee } \\
\text { - advices on consumer education } \\
\text { 360' Degree Forum - to increase discussion } \\
\text { about consumer-related regulations }\end{array}$ \\
\hline
\end{tabular}

Source: own depiction (based on European Commission 2011, 2012, 2013, 2014; German Federal Ministry of Food and Agriculture 2015)

Some main points emerge. Innovation and competition, for instance, are to be driven by the empowerment of the consumer (EC 2011). For the EU Consumer Strategy 2007-2013, over 55,000 face-to-face surveys with consumers were carried out (including Iceland and Norway, all aged $15+)$.

On the German side, since 2014 an independent committee of experts has the task to enhance the capacities of the German Consumer Policy. Regular assessments will ensure that policies are fitting better to consumer needs (German Government 2014).

Both EU and German policies have an elaborated plan on how to maintain and improve consumer safety and satisfaction. Nevertheless, the integration of the consumer and a relational approach in order to link the various actors are not much detailed. 
While structural changes such as the development and strengthening of Consumer Advice centres are considered important steps towards information distribution in order to guarantee consumers' safety and to enable their informed decision-making, research experts in Germany particularly highlight the need of evidence-based research to disseminate clear and transparent results. Questioning the existence of the "autonomous consumer" in general, experts argue for an approach including all actors in a multilevel engagement. As attitudes and routines hinder sustainable behaviours, niche innovations and experiments could unveil motives and open up new ways for sustainable changes. However, they need to be supported by current policies. The questions remain (i) of how much influence the German Council on Consumer Affairs and the European Commission will really have on policies, and (ii) of how much more focus is needed to transform the society. There is only a short proposal on sustainable consumption on both policy levels, and it is still unclear where to find concrete information. Consumers should be empowered, assisted and encouraged to make healthy life choices, and tools are needed to communicate the sustainability of products - but how to put all of this into practice? Webpages and updates alone will not be sufficient; active engagement could have the necessary triggering force. Sustainability science, thus, can give a first onset, showing that research is not only theoretical but also practically oriented and engaged, as well as able to include different actors.

Consumer research policies have importantly developed over the last years. However, distinct responsibilities have not yet evolved and the sustainability perspective has not necessarily been integrated from the beginning.

\section{Linkage between Consumer and Sustainability Research}

\subsection{Seeing Sustainability Science as Basis for Future-Compliant Consumer Policy}

If we are to link sustainability science and consumer research, a few aspects have first to be clarified. Therefore, within this chapter we will try to elucidate some models or approaches that can guide sustainability science and consumer research.

Liedtke \& Buhl (2015) define the suggestion of Schrader et al. (2003) as the leading one: "in terms of sustainable consumption it is interesting to note that the current definition of sustainable development, which focuses on needs' satisfaction, is ultimately affiliated to the term of consumption. With "consumption" we understand the attempt, with the help of market-mediated goods and services in the different stages of purchase, use and disposal, to achieve the satisfaction of needs. Based on this definition it becomes clear that in modern economy there is hardly any activity that does not involve consumption" (own translation, Schrader et al. 2013 p. 4). Consequently, if we define consumption as an essential part of sustainable development, we have to advance a new understanding of it. Sustainable consumption is then about a new design and organisation of products and services within an environmentally-, socially- and individually-focused thinking (Schrader et al. 2013, Liedtke $\&$ Buhl 2015). Consumption activities contribute to the satisfaction of needs - in respect to what related narratives tell us today. Thus, we have to develop a deeper understanding of "sustainable consumption" - a concept that, in the long run, leads also to recognize and appreciate alternative and non-consumptive behaviours including practices such as recycling, 
reusing, sharing or even rejection of consumption.

Research on sustainable consumption integrates different disciplines and theoretical approaches with the twofold aim of (i) trying to explain the forces underlying consumer behaviour, and (ii) elaborating policy instruments able to change it (Backhaus et al. 2013). The economic, ecological and social components of consumer behaviour are taken into consideration - and the need of going beyond a mere economic perspective becomes therefore clear. The framework within which consumers take their decisions, indeed, is formed not only by economic elements but also by socio-psychological factors (e.g. limited knowledge and cognitive capacity, rational and utility maximising behaviours, socio-cultural environment), as well as by technological and institutional conditions (such as goods supply and policy measures) (Kletzan et al. 2002).

Some of the constraining conditions, such as those posed by governments or businesses, can be changed only by a high number of consumers/citizens. What is important is, thus, not only what a single, individual consumer does: on a large scale, what matters is what large groups of consumers do (Thøgersen 2005). A consumer wanting or requested to act in an environmental-friendly way faces therefore a dilemma: from an individual point of view, sacrificing short-term utility/satisfaction for the "common good" is theoretically irrational, even more if this is to be realized only in the long term; however, if too few consumers act in this way, everyone will end up worse off than if they all have contributed. In the reality luckily - people often do not act following purely "rational" motivations but also prescriptive norms about their role/identity and the related behaviours (Thøgersen 2005).

Still, it has been showed that individuals are less likely to make sacrifices for the common good if they are uncertain about the contribution of other relevant actors. Consumers' motivations, hence, play an important role - together with their empowerment. In order to realize this latter, a consumer policy should aim (i) at reducing constraints that make the path towards a more sustainable lifestyle difficult on the individual level, and (ii) at fostering individual motivations, capabilities and propensity to initiate a change - and to persist in this direction (Thøgersen 2005). It is also to emphasize that the purpose and ultimate aim of producing, and of the whole supply chain economics, should be the consumer (Schrader et al. 2013 p.5). Liedtke \& Buhl (2015) suggest the following quintessence: not only one person or one consumer is responsible for certain actions; rather, we have to understand the interplay of mutual responsibilities of numerous actors in the field of production and consumption (also: Schrader et al. 2013).

Here, from our point of view, a multi-level approach would be helpful to understand future challenges (Geels et al. 2015, Schneidewind 2015, Schneidewind et al. 2015). If we apply this perspective and go towards the micro-level of the multi-level-perspective - that is, in our understanding, the level of individuals' actions - a distinction is usually done between situation, position or role. Actions have always a different function - sometimes more depending on jurisdiction and powers, sometimes rather from costs and prices, or ideas and arguments - and are accordingly characterised by different degrees of freedom. Overall, they remain complex and unpredictable, and the interdependencies between acts as a system and 


\section{Macrothink}

their impact on overarching institutions - such as globalized businesses, the supranational democracy in Europe or experience-oriented consumptions - are to be empirically observed, explained and understood.

Seeing the consumer, we have to consider several strong interdependencies (see Figure 2, simplified version - extended version see Liedtke et al. 2016, Liedtke et al. 2015c,d).

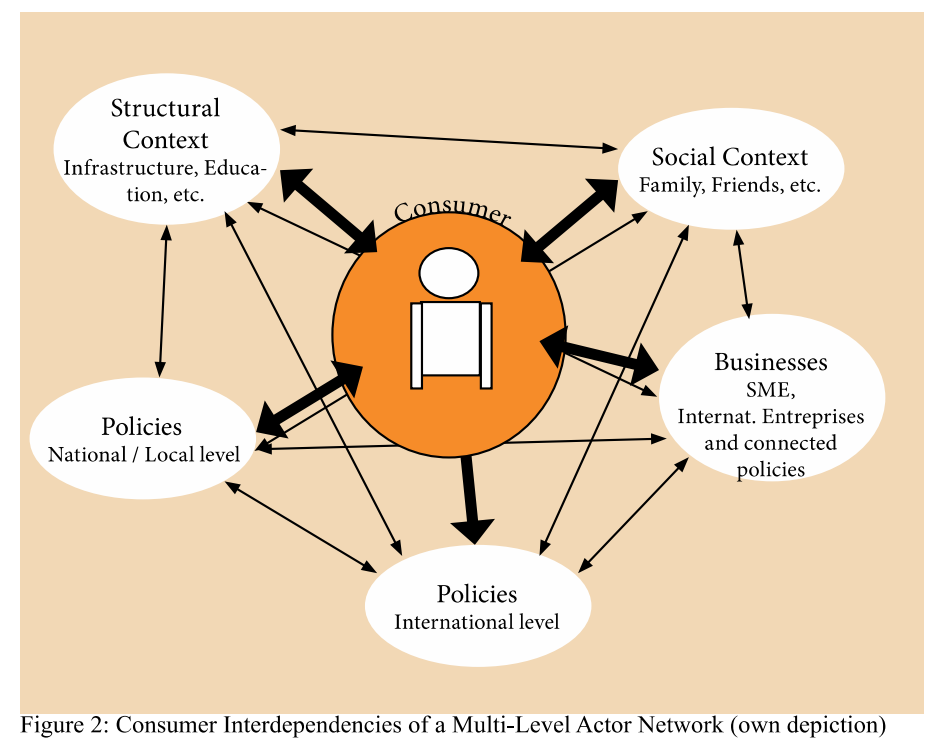

As illustrated in figure 2, structural contexts such as households and their consumptions play a role as prominent as that of companies and their value chains, and affect them as well as the surrounding structures (Speck 2016, Seibt 2015). Nevertheless, also businesses interact with consumers: we have therefore to set a model of action (Liedtke et al. 2013a, d, Kristof 2010) and a management model (Nordmann in prep., Geibler 2010, Baedeker 2012). The way of looking at the human behaviour becomes herewith more respectful and near to the reality (Liedtke et al. 2016).

For instance, changes or transitions of relevant, routinized practices require time. In everyday life (see Buhl \& Acosta 2015), decision-making processes are much more influenced by availability and infrastructure as often assumed: for example, decisions about daily food choices depend on foodstuff availability; consumers do not care about price, choice etc. in the first place. Consumer research and its assumptions have thus to consider social institutions such as working time regimes, but also public infrastructures such as roads or the structure of products and services supply in the private sector (see Liedtke et al. 2013b, c, 2015a, b), in a much more detailed way.

Social practices are a bridge that embeds social action in (infra)structural context. They are neither pure structure-phenomena nor individual actions, but understood as a (re)configured combination of materiality, competence and significance (Shove 2012, Giddens 1977). The analytical focus is on materiality in terms of infrastructures, technologies and objects, which is charged of significance in terms of symbols or ideas. Geels et al. (2015) describe the multi-level analysis and the analysis of social practices as coherent, and summarize both approaches under a "reconfiguration SCP-position" (Sustainable Consumption and 
Production). From the ecological sustainability perspective it is interesting, for example, how the materiality of practice changes according to the significance (Shove 2012). This is accompanied by a shift in the analytical perspective, where the focus is on the practice and where goods' materiality has to be explained in relation to practice and its significance. Consumption is, therefore, not to be explained through the accumulation of goods, but rather through the multiplicity of practices (Liedtke \& Buhl 2015). We will now try to develop a research agenda with the aim of addressing many different aspects - e.g. the dematerialisation of daily life in enterprises and households to protect ecosystem services, or resource-light economies and society (Schmidt-Bleek 1994, 2007) to reduce the resource use below 8 tonnes per person per year (Lettenmeier et al. 2014, Greiff et al. in prep.) Clearly, a comprehensive understanding of how households and consumers use natural resources and consume is essential.

\section{Ideas for a New Comprehensive Research Agenda}

Considering the complexity of the research, we have to address several points of intervention: routinized practices, in fact, always combine different areas of demand and activities with each other in a flexible timing. Nutrition, for example, can generally not be comprehended without considering also mobility/logistics and/or communication technologies (e.g. while driving to or from work/kindergarten shopping is done or foodstuff is ordered online).

Against this background, research requires interventions and intentional change. Liedtke \& Buhl (2015) point out a few examples - such as the so-called transformational objects or pleasurable troublemakers (among others: Laschke 2015, Hassenzahl \& Laschke 2014, Hassenzahl et al. 2013, Hassenzahl \& Diefenbacher 2012) ${ }^{3}$, which directly intervene in the context of action, interacting with the existing goods and infrastructures. They can only be done and tested together with the actors themselves (beneficiaries and users, as well as the system-affecting actors), as any change confuses daily routines and modifies the ingenious time regime up to the surrounding structures (e.g. different heating - changed heating/ventilation systems - changed energy-renovation policy Baedeker et al. 2014).

A structure for the development of such inventions and product service systems is offered by the so-called LivingLabs (in households and in businesses, e.g. Www.suslab.eu, www.innolab-livinglabs.de). On the field and in laboratories, they offer the possibility to explore incremental changes together with the affected actors and to carefully test both their effects on other subsystems as well as rebound effects, (Liedtke et al. 2012, 2015b, Baedeker et al. 2014, Geibler et al. 2014).

It is important to equip the existing database with intelligent interfaces, in order to observe the resource consumption of individual practices or actions on all levels. Sustainable

\footnotetext{
3 "Pleasurable troublemakers" disrupt existing practices and change moment of decision. In a given situation, they intervene and show action alternatives. The decision for one of the alternative courses of action remains a free choice of the user. This significant disruption of existing practices should serve as an impetus for reflection, and gives own actions meaning. Decisions should be consciously taken, and not without reflection. In the case studies (see also http://www.pleasurabletroublemakers.com, A.N.) it becomes clear that appeals and provision of information can influence behaviours only to a small extent. Still, they can have a greater influence on established behaviours (e.g. routines) (Laschke 2015 p. 63).
} 
consumption and its design, indeed, have to be learned and practiced in complex structures. The skills of those involved in LivingLabs projects, as well as of the scientists following the projects, are impressive (Liedtke \& Buhl 2015). Such projects, in fact, involve not only experiences in inter- and trans-disciplinary research but also a multifaceted competence base necessary to bring about and test resilient and resource-light system changes together with the players involved. For this, we need accurately designed exchange-relations between formal and informal education, and dedicated structural and temporal possibilities: social learning cannot be merely referenced to households or families, and formal education is not a feature only of education institutions. Actually, it is a fundamental social task that must be jointly designed. In this context, design and design research - mostly lacking in current consumer research - receive a new meaning (Mareis et al. 2013).

The analysis done by Liedtke \& Buhl (2015) of the German research activities in the field of consumer policy in recent years, exemplified by the statements and discussion papers of the Scientific Advisory Board for Consumer- and Food Policy, shows that many of the recommendations have been substantiated and strengthened. Still, a certain discrepancy and struggle about the different responsibilities are still visible. In particular, two points have often not been addressed: i) the consumer is not primarily interested in consuming, but in a satisfying and happy life; ii) consumer policy is about the sovereignty or the protection of the consumer in the act of consumption. Therefore it would be important, also to the consumer, to clearly distinguish in which areas of life he or she wants to/can take up responsibility - and in which not. This requires appropriate instruments throughout all stages of life and fields of activity: that is, politics should relate on correspondingly differentiated policy instruments which, too, are to evaluate in terms of functionality and effectiveness (Schrader et al. 2013).

However, the overall construction and understanding of consumer policy research does not necessarily include aspects of sustainability; it is traditionally often understood as pure research about consumption. The missing inclusion of the consumer as both an active and depending variable in consumer research has not yet been sufficiently addressed.

\section{Next Steps for an Innovative Consumer Research Including Sustainability Perspectives}

From the above it could be assumed that, up to now, no concrete solution has been presented to develop, both in the EU and in Germany, consumer policies actor-centred and evidence-based. A variety of programmes, whose aims range from making consumer behaviour quantifiable up to restricting unhealthy production materials or establishing a clear-cut policy framework for agriculture, has been developed on both levels. However, their comparison has shown that, in spite of the great effort, the necessary step towards a truly integration of the consumer, thus going beyond the mere keeping him/her interested in new websites and information databases, has not yet been done. We assume that e.g. a LivingLab approach may be useful to link several influential indicators dealing with the question: "Who are the consumers?". The approach we propose addresses the assumed consumers directly and has proven the need for a sustainability-integrated consumer research agenda. 
In order to meet the goals of a sustainable development, ideas about alternative consumption patterns and habits are essential, together with a broader understanding of what sustainability-linked consumer research agendas have to be about. To facilitate and simplify these processes, establishing a general plan is necessary. We propose nine points:

I. To clarify several valid action models for expressing consumer research on national, European and international level;

II. To elaborate a Research agenda independent from the general economic paradigm, dealing also with alternative consumption strategies, and considering the consumer not just as consumer, but more as citizen;

III. To create unique and clear structures in consumer research at national, European and international levels, ideally in cooperation with each other;

IV. To establish EU-wide Research funding for in-depth analysis of the consumer and everyday decisions fields;

$\mathrm{V}$. To focus on how to engage and inform the consumer/citizen, in order to profit from and further develop the already existing blogs, platforms and Consumer Advice Offices;

VI. To establish an organised structure of e.g. Commissions and Research Networks, both on the European and the national level, in order to improve transparency over current developments;

VII. To establish a sustainability-integrated consumer research within which the principles of sustainability are deeply integrated, and not simply putted on top;

VIII. To establish a consumer research strategy focussing on the LivingLab approach;

IX. To improve the ability of delivering and implementing policies without being disabled by markets and economic lobbies.

\section{References}

Backhaus, J., Breukers, S., Mont, O., Paukovic, M., \& Mourik, R. (2013). Sustainable Lifestyles: Today's Facts and Tomorrow's Trends. SPREAD Baseline Report D1.1. Retrieved from

http://www.sustainable-lifestyles.eu/fileadmin/images/content/D1.1_Baseline_Report.pdf

Baedeker, C. (2012). Regionale Netzwerke: Gesellschaftliche Nachhaltigkeit gestalten : am Beispiel von Lernpartnerschaften zwischen Schulen und Unternehmen. München: oekom Verlag.

Baedeker, C., Greiff, K, Grinewitschus, V., Hasselkuß, M., Keyson, D., Knutsson, J., Liedtke, C., Lockton, D., Morrison, G., van Rijn, M., Rohn, H., Silvester, S., van Harinxma, W., \& Virdee, L. (2014). Transition through sustainable Product and Service Innovations in Sustainable Living Labs: application of user-centred research methodology within four 


\section{MInstitute Macrothink $_{\text {Int }}$}

Environmental Management and Sustainable Development

ISSN 2164-7682 2016, Vol. 5, No. 2

Living Labs in Northern Europe. Paper presented at the 5th International Sustainable Transitions (IST) Conference, August 27-29, 2014 Utrecht, Netherlands.

Bliesner, A., Liedtke, C., Rohn, H. (2013). Change Agents für Nachhaltigkeit: Was müssen sie können? Führung + Organisation. Jg. 82, 1/2013. 49-53.

Bliesner A., Liedtke, C., Welfens, M. J., Baedeker, C., Hasselkuß, M., Rohn, H. (2014). Norm-Oriented Interpretation Learning and Resource Use: The concept of "open-didactic exploration" as a contribution to raising awareness of a responsible resource use. Resources. 3/2014, 1-30. http://dx.doi.org/10.3390/resources3010001

BMELV-Bundesministerium für Ernährung, Landwirtschaft und Verbraucherschutz (2003). Erlass über die Errichtung eines "Wissenschaftlichen Beirats Verbraucher- und Ernährungspolitik" beim Bundesministerium für Verbraucherschutz, Ernährung und Landwirtschaft. Berlin: 3. Februar 2003. [Online] Available: http://www.bmel.de/DE/Ministerium/Organisation/Beiraete/_Texte/ErlassBeiratVerbraucherE rnaehrungspolitik.html (August 03, 2015).

BMELV-Bundesministerium für Ernährung, Landwirtschaft und Verbraucherschutz (2013). Veröffentlichungen des Wissenschaftlichen Beirats "Verbraucher- und Ernährungspolitik". (Homepage). [Online] Available: (http://www.bmel.de/DE/Ministerium/Organisation/Beiraete/_Texte/VerbrVeroeffentlichunge n.html (August 03, 2015).

BMJV-Bundesministerium der Justiz und für Verbraucherschutz (2014a). 360grad. Das neue Debatten- und Meinungsforum im Bundesministerium der Justiz und für Verbraucherschutz. (Homepage). [Online] Available: http://www.bmjv.de/DE/WebS/360grad/start_node.html (July 31, 2015).

BMJV-Bundesministerium der Justiz und für Verbraucherschutz (2014b). Neuer Sachverständigenrat. Experten in Verbraucherfragen. (Homepage). [Online] Available: http://www.bundesregierung.de/Content/DE/Artikel/2014/11/2014-11-07-sachverstaendigenr at-verbraucherschutz.html (August 06, 2015).

BMJV - Bundesministerium der Justiz und für Verbraucherschutz (2014c): Erlass über die Einrichtung eines Sachverständigenrats für Verbraucherfragen bei dem Bundesministerium der Justiz und für Verbraucherschutz. Berlin: 21. Oktober 2014.

Buhl, J., \& Acosta, J. (2015). Work less, do less? Working time reductions and rebound effects. Sustainability Science, online first. Vol. 10. Tokyo, Osaka: Springer Japan.

Dreuw, K., \& Rohn, H. (2013). Instrumente zur Steigerung von Ressourceneffizienz und ihre Anknüpfungspunkte zur Umsetzung einer RessourcenKultur. In: Klinke, S., \& Rohn, H. (Hg.), RessourcenKultur - Vertrauenskulturen und Innovationen für Ressourceneffizienz im Spannungsfeld normativer Orientierung und betrieblicher Praxis, Nachhaltige Entwicklung (4). Baden-Baden: Nomos Verlag. 343-363. http://dx.doi.org/10.5771/9783845240138-343

European Commission (2011). Consumer Empowerment in the EU. Commission Staff 
Working Paper 07.04.2011, Brussels. [Online] Available: http://ec.europa.eu/consumers/consumer_empowerment/docs/swd_consumer_empowerment_ eu_en.pdf (October 12, 2015).

European Commission, (2012). 22.05.2012. Communication from the Commission to the European Parliament, the Council, the economic and social committee and the Committee of the regions. A European Consumer agenda - Boosting confidence and growth. [Online] Available:

http://ec.europa.eu/consumers/eu_consumer_policy/our-strategy/documents/consumer_agend a_2012_en.pdf (October 12, 2015).

European Commission (2013). Memo, Smarter rules for safer food: Commission proposes landmark package to modernise, simply and strengthen the agri-food chain in Europe. Brussels, 62 May $6013 . \quad$ [Online] Available: http://europa.eu/rapid/press-release_MEMO-13-398_en.htm (October 12, 2015).

European Commission (2014). Report on Consumer Policy. January 2012-December 2013. [Online] Available: http://ec.europa.eu/consumers/strategy-programme/policy-strategy/documents/consumer_poli cy_report_2014_en.pdf (October 12, 2015).

Federal German Government (2014). Experten in Verbraucherfragen. Artikel 07.11.2014. [Online]

Available: http://www.bundesregierung.de/Content/DE/Artikel/2014/11/2014-11-07-sachverstaendigenr at-verbraucherschutz.html (October 12, 2015).

Federal Ministry of Food and Agriculture (2015). Agrarpolitischer Bericht der budnesregierung 2015.2 [Online] Available: http://www.bmel.de/SharedDocs/Downloads/Broschueren/Agrarbericht2015.pdf?_blob=pub licationFile (October 12, 2015)

Fellner, W. (2014). Von der Güter- zur Aktivitatenokonomie: Zeitnutzung und endogene Präferenzen in einem Konsummodell. Wiesbaden: Springer Gabler. http://dx.doi.org/10.1007/978-3-658-04191-5

Geels, F. W., McMeekin, A., Mylan, J., \& Southerton, D. (2015): A critical appraisal of Sustainable Consumption and Production research: The reformist, revolutionary and reconfiguration positions. Global Environmental Change. 34, 1-12. http://dx.doi.org/10.1016/j.gloenvcha.2015.04.013

Geibler, J. v. (2010). Nachhaltigkeit in globalen Wertschöpfungsketten: Nicht-staatliche Standards als Steuerungsinstrument im internationalen Biomassehandel. Dissertationsschrift. Wirtschaftswissenschaftliche Nachhaltigkeitsforschung. Bd. 12. Marburg: Metropolis Verla

Geibler J. v., Erdmann, L., Liedtke, C., Rohn, H., Stabe, M., Berner, S., Leismann, K., Schnalzer, K., \& Kennedy, K. (2014). Exploring the Potential of a German Living Lab Research Infrastructure for the Development of Low Resource Products and Services. Journal Resources. 3/2014. 575-598. http://dx.doi.org/10.3390/resources3030575 
Giddens, A. (1997). Die Konstitution der Gesellschaft. Frankfurt a.M.: Campus.

Greiff K., Baedeker, C., Liedtke, C., Wiesen, K. (in prep.): Material Footprints, time use profiles and expenditures of Households of different social milieus - basis for behavior transitions.

Hassenzahl, M., Diefenbacher S. (2012). Well-being, need fulfillment, and Experience Design. DIS 2012: Workshop Designing Wellbeing, 11-12 June 2012, Newcastle, UK.

Hassenzahl, M., Eckoldt, K., Diefenbach, S., Laschke, M., Lenz, E., \& Kim, J. (2013). Designing Moments of Meaning and Pleasure. Experience Design and Happiness. International Journal of Design. 7(3). 21-31

Hassenzahl, M., \& Laschke, M. (2014). Pleasurable Troublemakers. In: S. Walz \& S. Deterding (Eds.), The Gameful World (pp. 167-195). Cambridge, MA: MIT Press.

Kletzan, D., Köppl, A., Kratena, K., Schleicher, S., \& Wüger, M. (2002). Modelling Sustainable Consumption: from Theoretical Concepts to Policy Guidelines. Empirica. 29, 131-144. http://dx.doi.org/10.1023/A:1015696710335

Kotakorpi, E., Lähteenoja, S., \& Lettenmeier, M (2008). Household MIPS: Natural resource consumption of Finnish households and its reduction (KotiMIPS - Kotitalouksien luonnonvarjen kulutus ja sen pienentäminen) Endbericht zum Projekt MIPS Household. Helsinki: Ministry of the Environment Environmental Protection Department, The Finnish Environment 43/2008.

Kristof, K. (2010). Models of Change: Einführung und Verbreitung sozialer Innovationen und gesellschaftlicher Veränderungen in transdisziplinärer Perspektive. Habilitationsschrift. Zürich: vdf Hochschulverlag.

KRU - Ressourcenkommission am Umweltbundesamt (Hg.), (2014). Ressourcenleicht leben und Wirtschaften: Standortbestimmung der Ressourcenkommission am Umweltbundesamt (KRU). [Online] Available: http://www.umweltbundesamt.de/sites/default/files/medien/378/publikationen/kru_standortbe stimmung_0.pdf (August 04, 2015).

Laschke, M., (2015). Der Einwand der Dinge: Pleasurable Troublemakers. Dissertation, Folkwang Universität der Künste, Essen.

Leismann, K., Schmitt, M., Rohn, H., \& Baedeker, C. (2012). Nutzen statt Besitzen: Auf dem Weg zu einer ressourcenschonenden Konsumkultur. Heinrich Böll Stiftung (Hg.): Schriften zur Ökologie (27). [Online] Available: https://www.boell.de/sites/default/files/Endf_NutzenStattBesitzen_web.pdf (August 04, 2015).

Leismann, K., Schmitt, M., Rohn, H., \& Baedeker, C. (2013). Collaborative Consumption: Towards a Resource-Saving Consumption Culture. Resources. 2/2013.184-203. http://dx.doi.org/10.3390/resources2030184 


\section{Mll Macrothink}

Environmental Management and Sustainable Development

ISSN 2164-7682

2016, Vol. 5, No. 2

Liedtke, C., Hasselkuss, M., Buhl J., Welfens, M. J., \& Baedeker, C. (2016): The role of social practices in transitions: heating by German households. Article under review for Environmental Innovation and Societal Transition, July 2015.

Liedtke, C., Welfens, M. J., Rohn, H., \& Nordmann, J. (2012). LIVING LAB: user-driven innovation for sustainability. International Journal of Sustainability in Higher Education, Vol. 13, 2/2012. 106-118. http://dx.doi.org/10.1108/14676371211211809

Liedtke, C., Hasselkuß, M., Welfens, M. J., Nordmann, J., \& Baedeker, C. (2013a). Transformation towards sustainable consumption: changing consumption patterns through meaning in social practices. Eidgenössische Techn. Hochschule Zürich. 702-729.

Liedtke, C., Buhl, J., \& Ameli, N. (2013b). Designing value through less by integrating sustainability strategies into lifestyles. International Journal of Sustainable Design. No. 2(2). 167-180. http://dx.doi.org/10.1504/IJSDES.2013.057124

Liedtke, C., Buhl, J., \& Ameli, N. (2013c). Microfoundations for sustainable growth with eco-intelligent product service arrangements. Sustainability, 5(3). 1141-1160. http://dx.doi.org/10.3390/su5031141

Liedtke, C., Hasselkuß, M., Welfens, M. J., Nordmann, J., \& Baedeker, C. (2013d). Transformation towards sustainable consumption: changing consumption patterns through meaning in social practices. In: 4th International Conference on Sustainability Transitions: IST; 18 - 21 June 2013. ETH Zurich, Switzerland. 702-729.

Liedtke, C., Baedeker, C., \& Borrelli, L. M. (2015a). Stellschrauben für Nachhaltigkeit: Trends und Verantwortungen in Produktion und Konsum. In: Roth, M., Ulbert, C., \& Debiel, TT.obias (Hg.) Stiftung Entwicklung und Frieden; Institut für Entwicklung und Frieden (pp. 299-314). Käte Hamburger Kolleg/Centre for Global Cooperation Research: Globale Trends 2015. Frankfurt a.M.: S. Fischer Verlag GmbH.

Liedtke, C., Baedeker, C., Hasselkuß, M., Rohn, H., \& Grinewitschus, V. (2015b). "User-integrated innovation in Sustainable LivingLabs: an experimental intrastructure for researching and developing sustainable product service systems. Journal of Cleaner Production. 97, 106-116. http://dx.doi.org/10.1016/j.jclepro.2014.04.070

Liedtke, C., Baedeker, C., \& Borrelli, L. M. (2015c). A Road Map for Sustainable Production and Consumption: Trends and Responsibilities. In Roth M., Ulbert C., \& Debiel T. (Eds.), Global Trends (2015). Prospects for World Society (pp. 283-297). Frankfurt a.M.: Fischer Taschenbuch Verlag.

Liedtke, C., Baedeker, C., \& Borrelli, L.M. (2015d). Transformation towards a Sustainable Society: Key Intervention Area. Innovative Energy Policies. 4, 118(2). 1-10.

Liedtke, C., \& Buhl, J. (2015). Wer sind die Verbraucher? - von der Un/Mündigkeit bis zum Management komplexer Systeme. In Romahn \& Rehfeld (Ed.): Lebenslagen - Beitröge zur Gesellschaftspolitik. Marburg: Metropolis.

Lukas, M., Liedtke, C., Welfens, M. J., \& Baedeker, C. (2014). Suffizienz als 
Anknüpfungspunkt für ein nachhaltiges Handeln des verletzlichen Verbrauchers. In C. Bala \& K. Müller (Eds.), Der verletzliche Verbraucher: Die sozialpolitische Dimension der Verbraucherpolitik. Beiträge zur Verbraucherforschung (pp. 99-121). Düsseldorf: Verbraucherzentrale NRW. [Online] Available: http://epub.wupperinst.org/frontdoor/index/index/docId/5270 (October 12, 2015).

Mareis C., Held, M., \& Joost, G. (Hg.) (2013). Wer gestaltet die Gestaltung? Praxis, Theorie und Geschichte des partizipatorischen Designs. Bielefeld: Transcript Verlag. http://dx.doi.org/10.14361/transcript.9783839420386

Nordmann, J. (in. prep.): Nachhaltigkeit im Unternehmensmanagement und der Unternehmenskommunikation: Case Study Autostadt GmbH

Oehler, A., \& Kenning, P. (2013). Evidenzbasierung ermöglichen! Auf dem Weg zu einer realitätsnahen und empirisch fundierten Verbraucherpolitik. [Online] Available: http://www.bmel.de/SharedDocs/Downloads/Ministerium/Beiraete/Verbraucherpolitik/2013_ 09_EvidenzbasierteVerbraucherpolitik.pdf?_blob=publicationFile (August 04, 2015).

Oehler, A., \&, Reisch, L. A. (2008). Behavioral Economics: eine neue Grundlage für die Verbraucherpolitik? Studie im Auftrag des VZBV, Berlin.

Schmidt-Bleek, F. (1994). Wieviel Umwelt braucht der Mensch? MIPS, das Maß für ökologisches Wirtschaften. Berlin, Basel, Boston: Birkhäuser. http://dx.doi.org/10.1007/978-3-0348-5650-8

Schmidt-Bleek, F. (2007). Nutzen wir die Erde richtig?. Frankfurt a.M.; Fischer-Taschenbuch-Verlag.

Schneidewind, U. (2015). Verantwortung für die Gesellschaft, Wissenschaft in der großen Transformation. Politische Ökologie (140): Forschungswende, Wissen schaffen für die Große Transformation. München: oekom verlag.

Schneidewind, U., Fischedick, M. Lucas, R., Müller, M., Reutter, O., Schüle, R., Vallentin, D., Venjakob, J., \& Wanner, M. (2015). „Städte in Schwung bringen: Vier Prinzipien der urbanen Transformation. Ökologisches Wirtschaften, 02. 20-22. http://dx.doi.org/10.14512/OEW300220

Schrader, U., Liedtke, C., Lamla, J., Arens-Azevêdo, U., Hagen, K., Jaquemoth, M., Kenning, P., Schmidt-Kessel, M., \& Strünck, C. (2013). Verbraucherpolitik für nachhaltigen Konsum. Verbraucherpolitische Perspektiven für eine nachhaltige Transformation von Wirtschaft und Gesellschaft. [Online] Available: http://www.bmel.de/SharedDocs/Downloads/Ministerium/Beiraete/Verbraucherpolitik/2013_ 12_NachhaltigerKonsum.pdf?_blob=publicationFile (August 04, 2015).

Schrader, U., Thøgersen, J. (2011). Putting Sustainable Consumption into Practice. Journal of Consumer Policy. 34, 3-8. http://dx.doi.org/10.1007/s10603-011-9154-9

Seibt, A. (2015). Lobbying für erneuerbare Energien. Wiesbaden: Springer VS. http://dx.doi.org/10.1007/978-3-658-09259-7 
Sheth, J., Sethia, N. K. (2011). Mindful consumption: a customer-centric approach to $\begin{array}{lllll}\text { sustainability. Journal of } & \text { Consumer } & \text { Policy. }\end{array}$ http://dx.doi.org/10.1007/s11747-010-0216-3

Shove, E. (2012). The dynamics of social practice: everyday life and how it changes. Los Angeles: SAGE. http://dx.doi.org/10.4135/9781446250655.n1

Speck, M. (2016). Konsum und Suffizienz-Eine empirische Untersuchung deutscher Haushalte. Wiesbaden: Springer VS.

Stengel, O., Liedtke, C., Baedeker, C., \& Welfens, M. J. (2008). Theorie und Praxis eines Bildungskonzepts für Nachhaltigkeit. Umweltpsychologie, 12. Jg., 2/2008. 29-42.

Stengel, O. (2011). Suffizienz: die Konsumgesellschaft in der ökologischen Krise, Dissertationsschrift, Wuppertaler Schriften zur Forschung für eine nachhaltige Entwicklung (1). München: Oekom verlag.

Strünck, C. (2010). Wollen wirklich alle den “mündigen Verbraucher"? Wie Interessengruppen ein Leitbild instrumentalisieren. [Online] Available: http://www.bmel.de/SharedDocs/Downloads/Ministerium/Beiraete/Verbraucherpolitik/2010_ 12_InteressengruppeMuendigerVerbraucher.pdf?_blob=publicationFile (August 04, 2015).

Strünck, C., Arens-Azevêdo, U., Brönneke, T., Hagen, K., Jaquemoth, M., Kenning, P., Liedtke, C., Oehler, A., Schrader, U., \& Tamm, M. (2012). Ist der „mündige Verbraucher“ ein Mythos? Auf dem Weg zu einer realistischen Verbraucherpolitik. [Online] Available: http://www.bmel.de/SharedDocs/Downloads/Ministerium/Beiraete/Verbraucherpolitik/2012_ 12_MuendigerVerbraucher.pdf?_blob=publicationFile (August 04, 2015).

Thøgersen, J., (2005). How May Consumer Policy Empower Consumers for Sustainable Lifestyles? Journal of Consumer Policy. $28 . \quad 143-178$. http://dx.doi.org/10.1007/s10603-005-2982-8

Weisser, G. (1978). Beiträge zur Gesellschaftspolitik. Göttingen: Schwartz \& Co.

Zaccaï, E., 2008. Assessing the role of consumers in sustainable product policies. Environ Dev Sustain. 10, 51-67. http://dx.doi.org/10.1007/s10668-006-9038-3

\section{Copyright Disclaimer}

Copyright for this article is retained by the author(s), with first publication rights granted to the journal.

This is an open-access article distributed under the terms and conditions of the Creative Commons Attribution license (http://creativecommons.org/licenses/by/3.0/). 